\title{
Contribution of L1 in EFL Teaching
}

\author{
Wahjuningsih Usadiati \\ English Education Study Program, Faculty of Teacher Training \\ and Education, Palangka Raya University, Yos Sudarso, Palangka Raya \\ 73111A, Central Kalimantan, Indonesia \\ e-mail:wusadiati@yahoo.com
}

\begin{abstract}
This study is conducted in a classroom action research to improve the students' achievement in writing English sentences in Present Perfect Tense in Structure 1 lessons. The subject consisted of 20 Semester II students who took Structure I lessons in English Education Department of Palangka Raya University, Central Kalimantan, Indonesia. The data were taken from the results of pre test and post test after the action was done. The results show that in cycle 1, in which the explanations were fully in English, only $40 \%$ of the students got a good achievement; 5-7 out of 20 test items were correct. After cycle 2 was done using L1 interchangeably with English in the explanations, the students' achievement of writing English sentences in Present Perfect Tense increased to 75\%, in which 15-18 out 20 test items were correct.
\end{abstract}

Key words: L1, L2, EFL

Why should teachers use L1 in EFL classes? As stated by Carless (2008), L1 has potentially both positive and negative consequences. It may serve social and cognitive functions. Socially it serves to give instructions and rules, to establish attention, or to foster discipline, and to support classroom management, while cognitively it facilitates the students' understanding. He claimed that students working in group do not necessarily speak English all the time; therefore, L1 also occurs in the discussions since the students are linguistically incapable of activating English words and meanings.

In the field of foreign language teaching especially English, various other professionals also agreed with the above statement that L1 has a necessary and facilitating role in L2 classrooms. For example, Auerbach (1999) pointed out that to start the classroom interactions using L1 provided a sense of security and validated the learner's live experiences. Pillay and Hwa (1997) even felt the disempowerment of monolingual English classes in EFL teaching in Malaysia, and Melayu language (L1) was also used instead of only English. They showed that in rural 
Malaysian schools, there was a sense of awkwardness in using solely L2 to communicate in the classrooms. Moreover, Ellis and Kelly (1997) studied the role of Lao language (L1) and English (L2) in EFL classrooms, and the majority viewed L1 and L2 were to be used interchangeably in the English classroom interactions.

Kavaliauskiene's findings (2009) also demonstrated the need of L1 in English classes, although the amount of L1 depends on the students' proficiency in English. This implicitly means that the students' proficiency also determines the use of L1 in EFL classes.

In Indonesia, the term mostly used in the English teaching is English as a Foreign Language (EFL). Foreign language context is the one in which the students do not have ready-made contexts for communication beyond their classrooms. English is taught as the first foreign language with the objectives to make students to be able to read textbooks and other informative materials, and it is considered as a compulsory subject in the tertiary education (Achmad, 1997) and the secondary education (Dardjowidjojo, 1997). Usadiati (2003) in her case study in a tertiary education stated that the use of L1 in EFL (in this case, ESP) classrooms was deemed more communicative to arouse the students' live experiences that allowed them to express themselves in L1 first, then in English. This was done for the purpose of comprehending the context of English sentences that the teacher made for adaptations and modifications. They included various types; among others was the use of L1 in the classroom teaching, interchangeably with L2. The use of monolingual L2 in EFL teaching was recognized as a constant source of tension, and her evidence showed positive effect of L1 as long as it was judiciously used to enhance learning.

The English Education Department of Palangka Raya University, Central Kalimantan, Indonesia is one of the departments that uses English as the language of instruction. This is with the consideration to familiarize the students with English so that after they are graduated they can use English communicatively.

In the 2007 Curriculum of English for Semester II students of English Education Department of Palangka Raya University, it is stated that the basic competence of the students is to master the four skills of English: listening, speaking, reading, and writing. One of the indicators of the success of the students in the four English skills above is that they are able to construct sentences in Present Perfect Tense. However, in the previous observation the students who took Structure 1 lessons faced many problems in making sentences in Present Perfect Tense. They did 
not understand well the teacher's explanations on the agreement between the subject and the verb; they just used Verb III form without considering the use of auxiliary of 'have/has' since the teacher's explanation was completely in English.

Based on the above discussion, the writer intended to do a study using classroom action research method in Structure I lessons to improve the students' achievement in constructing sentences in Present Perfect Tense.

\section{METHODS}

This study used classroom action research method with the objective to improve the students' achievement in constructing sentences in Present Perfect Tense. This classroom action research followed Hopkins (1993) with two cycles, and it was conducted as the following:

\section{Setting and Subject}

The setting of the classroom action research was the English Education Department, Palangka Raya University, in Central Kalimantan, Indonesia. The subjects consisted of twenty out of forty students who took Structure I lessons in the remedial classes with zero credit in Semester II, academic year 2008/2009. Since it was given zero credit, not all of the students were willing to join the class. They graduated in 2007 from general senior high schools in Central Kalimantan Province with unsatisfactory English proficiency. They got Intensive Course in Semester I, during which they got a general review of the constructions of Present Perfect Tense sentences. The other subject of the study was a non-native English teacher who taught Structure 1 lessons in Semester II, academic year 2008/2009. She was graduated from a private English Education institution in 1986 and has been teaching English at the English Education Department of Palangka Raya University since 1992.

\section{Procedures}

This classroom action research was conducted in two cycles and each cycle consisted of the scenario of teaching the constructions of Present Perfect Tense sentences prepared in the Lesson Plans. The scenario was prepared using five categories as follows: 
Category 5 = teacher's use of 100\% English in the explanation

Category 4 = teacher's use of 75\% English and 25\% L1 in the explanation

Category $3=$ teacher's use of 50\% English and 50\% L1 in the explanation

Category 2 = teacher's use of 25\% English and 75\% L1 in the explanation

Category 1 = teacher's use of $100 \%$ L1 in the explanation

(adapted from Grant, 1991 and Dinas Pendidikan dan Kebudayaan Provinsi Kalimantan Tengah/Regional Office of the Department of Education and Culture, Central Kalimantan Province, 2003).

The categorization of the teacher's use of English or L1 in the explanation was determined from her verbal expressions; when almost all of her explanations were in English it was considered as 75\% English and 25\% L1, and when she expressed them mostly in Indonesian then it was considered as 75\% L1 and 25\% English.

The procedures of this classroom action research consist of the following stages:

\section{Stage 1: Planning}

In this stage, planning was done by preparing the scenario of the teaching and learning process in the Lesson Plans. The Lesson Plans consisted of teaching Present Perfect Tense in three consecutive meetings. A pretest, a formative test, and a posttest containing items of sentences in Present Perfect Tense were prepared to know the students' progress in writing English sentences using Present Perfect Tense. The data were obtained from the results of the tests made in the form of Completion Test of the correct form of the verbs in question. Reliability and validity of the test were not measured since the test items were taken from the prepared ones by Azar (1989) that they were assumed to be reliable and valid. The pretest, formative test, and posttest were similar in forms, that is, 20-item Completion Test, but the sentences to be constructed using Present Perfect Tense in the test items were different. Sample of the test is presented in Appendix 1. No statistical analysis was used in calculating the students' achievements; calculation was only done on the students' answers (as the data) using percentage based on the formula stated by Dinas Pendidikan dan Kebudayaan Provinsi 
Kalimantan Tengah (Regional Office of the Department of Education and Culture, Central Kalimantan Province) (2003) as follows:

$$
A=\frac{F}{N} \times 100 \%
$$

In which:

A = achievement

$\mathrm{F} \quad=$ number of correct answers

$\mathrm{N} \quad=$ number of items

$100 \%$ = constant multiplier

An observation sheet was also prepared to guide the observation of the teacher's explanations for the students in constructing sentences in Present Perfect Tense. The observation sheet was formatted based on the following categories:

\section{Stage 2: Acting}

In this stage, first the students were asked to do the pretest. After the pretest, the teacher taught the construction of sentences using Present Perfect Tense for two meetings using category 5 (100\% of the teacher's use of English in the explanations). In the third meeting, a formative test was conducted to know the students' achievement.

\section{Stage 3: Observing}

In this stage, the observer, who was also the collaborator, observed the conduct of teaching the construction of sentences in Present Perfect Tense using 100\% English as stated in the Acting Stage. She was equipped with the observation sheet prepared in the Planning Stage above, in which she put a check mark on the observation sheet according to the amount of English and L1 used. She also noted down the teacher's activities in the teaching and learning process.

\section{Stage 4: Reflecting}

In this stage, the teacher and the observer discussed the results of the pretest and formative test, as well as the results of the observation on the teaching and learning process. Based on the result of reflecting, both of them would determine whether or not to conduct cycle 2 to improve the students' achievement in constructing sentences in Present Perfect Tense. 


\section{FINDINGS AND DISCUSSION}

There was no action conducted before the pretest was given. In meeting 1 , the students were asked to answer the questions in constructing sentences in Present Prefect Tense without any explanations before. As stated in Table 1, the result of pretest showed that the students' achievement of writing sentences in Present Perfect Tense was low, as indicated by only $40 \%$ of them (eight out of twenty students) had five to six correct answers out of twenty test items. The rest, i.e. $60 \%$ of them (twelve out of twenty students) got two to four correct answers only.

\section{Table 1. Result of Pretest}

\begin{tabular}{cccc}
\hline No. & $\begin{array}{c}\text { Student's } \\
\text { Code }\end{array}$ & $\begin{array}{c}\text { Number of correct } \\
\text { items }\end{array}$ & $\begin{array}{c}\text { Achievement } \\
\text { (\%) }\end{array}$ \\
\hline 1 & LN & 6 & 30 \\
2 & MT & 6 & 30 \\
3 & DW & 5 & 25 \\
4 & YN & 5 & 25 \\
5 & DD & 5 & 25 \\
6 & ER & 5 & 25 \\
7 & FT & 5 & 25 \\
8 & IC & 5 & 25 \\
9 & NL & 4 & 20 \\
10 & PP & 4 & 20 \\
11 & AE & 3 & 15 \\
12 & DP & 3 & 15 \\
13 & LM & 3 & 15 \\
14 & NA & 3 & 15 \\
15 & PH & 3 & 15 \\
16 & SA & 3 & 15 \\
17 & ML & 2 & 10 \\
18 & MU & 2 & 10 \\
19 & RS & 2 & 10 \\
20 & YF & 2 & 10 \\
\hline
\end{tabular}

Note: Number of test items: 20 
In meeting 2, as had been determined in the scenario in the Lesson Plan, the teacher explained the constructions of sentences in Present Perfect Tense using category 4 (75\% English and 25\% L1 in the explanations). As stated in Table 2, the result of the formative test done in meeting 3 was still low. This is shown by $45 \%$ of them who got only seven to nine correct answers out of twenty test items. Although the number of correct items increased, the number of students who got a higher number of correct answers (seven to nine correct answers out of twenty items) was only nine out of twenty students.

Table 2. Result of Formative Test

\begin{tabular}{cccc}
\hline No. & $\begin{array}{c}\text { Student's } \\
\text { Code }\end{array}$ & $\begin{array}{c}\text { Number of correct } \\
\text { items }\end{array}$ & $\begin{array}{c}\text { Achievement } \\
\mathbf{( \% )}\end{array}$ \\
\hline 1 & DW & 9 & 45 \\
2 & MT & 9 & 45 \\
3 & YN & 9 & 45 \\
4 & DD & 8 & 40 \\
5 & ER & 8 & 40 \\
6 & LN & 8 & 40 \\
7 & AE & 7 & 35 \\
8 & FT & 7 & 35 \\
9 & IC & 7 & 35 \\
10 & DP & 6 & 30 \\
11 & LM & 6 & 30 \\
12 & NL & 6 & 30 \\
13 & PP & 6 & 30 \\
14 & NA & 5 & 25 \\
15 & PH & 5 & 25 \\
16 & SA & 5 & 25 \\
17 & ML & 5 & 25 \\
18 & MU & 4 & 20 \\
19 & RS & 4 & 20 \\
20 & YF & 4 & 20 \\
\hline
\end{tabular}

Note: Number of test items: 20

Since the result above was still unsatisfactory, both the teacher and the observer determined to conduct Cycle 2. The cycle was done with 
the same stages as in Cycle 1, but it was only in one meeting. In this fourth meeting, the teacher intended to use category 3 (50\% English and $50 \%$ L1) in explaining the constructed sentences in Present Perfect Tense, as stated in the scenario in the Lesson Plan. After the Acting Stage of Cycle 2 had finished, the posttest was given to the students.

The result of posttest was encouraging. As stated in Table 3, 80\% of the students got twelve to sixteen correct answers. The teacher used category 3, in which 50\% of her explanations was in English and 50\% was in L1.

Table 3. Result of Post Test

\begin{tabular}{cccc}
\hline No. & $\begin{array}{c}\text { Student's } \\
\text { Code }\end{array}$ & $\begin{array}{c}\text { Number of correct } \\
\text { items }\end{array}$ & $\begin{array}{c}\text { Achievement } \\
\text { (\%) }\end{array}$ \\
\hline 1 & DD & 16 & 80 \\
2 & DW & 16 & 80 \\
3 & ER & 16 & 80 \\
4 & MT & 16 & 80 \\
5 & YN & 16 & 80 \\
6 & DP & 15 & 75 \\
7 & FT & 15 & 75 \\
8 & IC & 15 & 75 \\
9 & LM & 14 & 70 \\
10 & LN & 14 & 70 \\
11 & AE & 14 & 70 \\
12 & NL & 13 & 65 \\
13 & PP & 13 & 65 \\
14 & ML & 12 & 60 \\
15 & MU & 12 & 60 \\
16 & PH & 12 & 60 \\
17 & NA & 9 & 45 \\
18 & RS & 9 & 45 \\
19 & SA & 9 & 45 \\
20 & YF & 9 & 45 \\
\hline
\end{tabular}

Note: Number of test items: 20

The above results show the contributive use of L1 in enhancing learning. As stated by Nunan (2001), in non-English speaking classes, a 
learner's L1 has a necessary impact on the acquisition of L2. As we know, in non-native English speaking countries like Indonesia, the rules of L1 and English are in conflict so that errors which are the result of inter-reference between L1 and L2 are likely to occur. This 'negative transfer' of the rule of L1 interfered the use of L2, which means the use of mostly English in the explanations might not facilitate learning. In this study, when $75 \%$ English was used in the explanations, the result of post test was better although only $45 \%$ of the students answered the question items correctly in the formative test. The L1 (in this case, Bahasa Indonesia) and English have different rules; the students do not have the present perfect tense in their vernacular and they just put the verb as it is without considering the other necessities. This reflects the degree of 'markedness' of both languages and this is not easy to explain solely using English that L1 plays a positive role. And since the understanding of concept of tense is more necessary, the use of L1 in the explanations was doubtlessly positive.

Why should teacher use L1 in EFL classes? As stated by Carless (2008), L1 has potentially positive consequences of cognitive functions. It was testified that one of the most frustrating aspects of teaching EFL is lack of meaningful communication when only L2 is used in the classroom. As shown in the results of this study, for example, when the use of L1 is prohibited in the EFL classroom, then it may preclude progress of the students, which may in turn impede learning. When L1 is also used, however, encouraging results are obtained. The progress in English is better: in this study, 50\% English and 50\% L1 resulted in 80\% of the students' achievement. This supports Schweers (1999) who claimed that approximately $99 \%$ of the students liked their teachers to use at least some L1 in their EFL, 86\% to explain difficult concepts that L1 would facilitate their comprehension. As also experienced by Usadiati (2007, personal experience) in her EFL classroom, the use of L1 really improved her first year students' comprehension. Almost the same number of students (88\%) preferred to have L1 for the elaboration of the explanation combined with L2. She agrees with the proposition that the teacher should be encouraged not to submerge the students completely in L2; the development of L1 skills is believed to be of importance for adequate cognitive, social, and educational growth. There is no conflict of social prestige between the L1 and L2, especially in the scope of Central Kalimantan, that the use of L1 is still encouraged, interchangeably with English. 
It is known that the freshmen at the English Education Department of Palangka Raya University were still unsatisfactory in their English proficiency; that's why L1 should still be maintained. When $75 \%$ English was used in the explanation of difficult concept like the rules of present perfect tense, only $45 \%$ of the students achieved a good result; when 50\% English was used then the result increased to 80\%. These results support Ellis and Kelly's results (1997) that L1 should not be minimized. As also stated by Mattioli (2004) and Kavaliauskiene (2009), L1 should still be maintained and be used more especially in explaining difficult concepts. They further stated that it was not the question of 'how much' L1 and L2 should be used, but 'for what purpose'. Since in this present study the purpose is to explain difficult concept of present perfect tense rules, then the use of $\mathrm{L} 1$ is positive.

The extent of teaching EFL should also be viewed from the perspective of the non-native English teachers. The native speaker teachers hold a favored position in the profession despite the fact that they may know little or nothing about the learners' L1 and culture. In fact, both native and non-native English teachers have their own strengths and weaknesses (Ellis \& Kelly, 1997). This study found that for Dayak students in Central Kalimantan, Indonesia, L1 was also used for various purposes of classroom management and organization. In presenting rules of grammar, the teacher in this study, as a non native speaker of English, used L1 to explain the concept of rules of Present Perfect Tense that should be comprehended by her students. She did this by interchanging her explanations in English with L1 to anticipate the students' difficulties with English in their beginning period of their EFL classes. English was mostly used by the teacher when practicing the drills on the use of a certain rule of Present Perfect Tense, so that with the English rules or models in drills it was expected that the students learned comprehensively on the use of Present Perfect Tense rules in their final production.

To find a support on the use of L1 in EFL, Schweers (1999) prepared a questionnaire and asked the teachers to state how frequent and for what purpose they used L1 in their EFL classes. It was indicated that $100 \%$ of them agreed to use L1 in classroom interactions for the purpose to aid comprehension. This is in line with the results of the study; using 50\% L1 in EFL classrooms helps the students learn the English language. In this present study, the occasions for using L1 are to present rules of grammar to enhance comprehension. 


\section{CONCLUSION AND SUGGESTIONS}

The present study was conducted in a classroom action research with the objective to improve the students' achievement in writing sentences in Present Perfect Tense. This was done by using L1 interchangeably with English in the explanations of concepts and rules of the tense. Although there was an individual improvement of achievement among the students, their general achievement has not been very satisfactory. The general increase of achievement is only from $45 \%$ to $75 \%$, which means that this classroom action research should still be continued.

The appropriateness on the use of L1 goes back to teacher to justify very cautiously when is appropriate to use L1 or L2 in EFL classrooms. Whenever content (or concepts) is more emphasized, which means comprehending meaning is more important, then the use of L1 may be encouraged to enhance learning. Further studies with similar topics should be made in order to ensure whether the categorization of the teacher's explanation is reliable.

\section{REFERENCES}

Achmad, N. (1997). Addressing language and communication: Issues in university development. Paper presented at the Third International Conference on Language in Development: Access, Empowerment, Opportunity, Langkawi, Malaysia.

Auerbach, E. (1999). Reexamining English only in the ESL classroom. TESOL Quarterly, 27, 9-32.

Azar, B.S. (1989). Understanding and using English grammar. New Jersey: Prentice Hall Regents.

Carless, D. (2008). Student use of mother tongue in the task-based classroom. ELT Journal 62(4), 331-338.

Dardjowidjojo, S. (1997). English policies and their classroom impact in some ASEAN-Asian countries: Language classroom of tomorrow issues and trends. Anthology Series, 38, 42-55.

Dinas Pendidikan dan Kebudayaan Provinsi Kalimantan Tengah (Regional Office of the Department of Education and Culture). (2003). Petunjuk Teknis Penyelenggaraan Workshop Pemantapan Penulisan Proposal 
PTK (CAR). (Technical Manual for the Workshop on Writing CAR Proposal). Palangka Raya: Regional Office of the Department of Education and Culture.

Ellis, L., \& Kelly, S. (1997). Cross cultural teacher education: Issues and values in the Lao context. Paper presented at the Third International Conference on Language in Development: Access, Empowerment, Opportunity, Langkawi, Malaysia.

Grant, N. (1991). Making the most of your textbook. London : Longman.

Kavaliauskiene, G. (2009). Role of mother tongue in learning English for specific purposes. ESP World, 1-8(22). Retrieved March 6, 2009, from http://www.esp-world.info

Hopkins, D. (1993). A teacher's guide to classroom research. Philadelphia: Open University Press.

Mattioli, G. (2004). On native language intrusions and making do with words: Linguistically homogenous classroom and native language use. English Teaching Forum, 42(4), 20-25.

Nunan, D. (2001). Second language acquisition. The Cambridge Guide to Teaching English to Speakers of Other Languages. Cambridge: Cambridge University Press.

Pillay, H., \& Hwa, Y. P. (1997). Language and empowerment : The role of the first language (L1) in the teaching of English. Paper presented at the Third International Conference on Language in Development: Access, Empowerment, Opportunity. Langkawi, Malaysia.

Schweers, C. W. Jr. (1999). Using L1 in L2 classrooms. English Teaching Forum, 37(2), 6-13.

Usadiati, W. (2003). The use of L1 in EFL for comprehension: Enhancing or impeding learning? Pancaran Pendidikan, 55, 48-58. 


\section{APPENDIX 1: SAMPLE TEST}

Complete the following sentences with the correct verb in brackets using Present Perfect Tense.

1. I (attend, not) ..................... any parties since I came here.

2. Annie (go) ................................ to the party at Sally's apartment when Henry arrived.

3. Billy (arrive) .............................. here since the $22^{\text {nd }}$.

4. Try not to be absent from class again for the rest of the term. You (miss, already) ..................... too many classes.

5. In her whole lifetime, Anna (see, never) ................... snow

6. I (know) .......................... Greg Adams for ten years.

7. So far this week, I (have) ....................... two tests and a quiz.

8. Up to now, Professor Williams (give) .................. our class five tests.

9. What (learn, you) .......................... since you came here?

10. How many new friends (made, you) ................... since your arrival in New York?

11. Since classes began, I (have, not) ................. much free time.

12. I admit that I (get) ..................... older since I last saw you.

13. The science of medicine (advance) ................... a great deal in the nineteenth century.

14. Since the beginning of the twentieth century, medical scientists (make) ............................ many important discoveries.

15. The contents of libraries (change) ................. greatly through the years.

16. Are you taking Chemistry 101 this semester?

No. I (take, already) .................................. it.

17. Hi, Judy. Welcome to the party. (meet, you, ever) ........ my cousin?

18. Do you like lobster? I don't know. I (eat, never) ............ it before.

19. I like traveling. I (be) ..................... in India, Turkey, Afghanistan, and Nepal, among others.

20. I went to England six years ago, but I (go, not) ........ anywhere since then. 